\title{
PENILAIAN KADAR AIR, PH DAN KOLONI BAKTERI PADA PRODUK DAGING BABI MERAH DI KOTA MANADO
}

\author{
Maruli Sitompul*, E. Siswosubroto**, Delly Rumondor**, M. Tamasoleng**, \\ S. Sakul**
}

Fakultas Peternakan Universitas Sam Ratulangi Manado, 95115

\begin{abstract}
ABSTRAK
Daging babi merah merupakan salah satu olahan yang banyak disukai oleh konsumen terutama di kota Manado karena memiliki cita rasa yang khas dan lezat. Namun disisi lain daging babi merah yang dijajakan pada beberapa rumah makan di Kota Manado mempunyai kuaitas yang berbeda-beda. Perbedaan ini umumnya terletak pada; cara pengolahan, sumber daging, formulasi bumbu dan perlakuan serta lamanya pengasapan. Kualitas daging dapat dipertahankan dengan cara penambahan $\mathrm{NaCI}$, gula, bumbu serta pengasapan dan perlu dilakukan penanganan yang terkontrol secara baik mulai dari daging mentah sampai masak.Tujuan penelitian adalah untuk mengetahui kadar air, $\mathrm{pH}$ dan koloni bakteri daging merah yang dijajakan pada beberapa rumah makan yang ada di Kota Manado. Penelitian ini dilaksanakan dengan kegiatan berupa pengambilan sampel dari beberapa rumah makan dan analisa sampel dilakukan di laboratorium dengan menganalisa kadar air,pH dan koloni bakteri dari daging babi merah. Metode Penelitian yang digunakan yakni deskriptif untuk memecahkan masalah dengan menggambarkan keadaan subyek penelitian berdasarkan fakta-fakta yang tampak sebagaimana adanya. Dari hasil penelitian didapatkan bahwa daging babi merah yang dijajakan pada rumah makan di Kota Manado memiliki rata-rata kadar air terendah pada lokasi A $(39,1 \%)$ dan tertinggi pada lokasi $\mathrm{G}(56,34 \%)$ untuk rata-rata $\mathrm{pH}$ terendah pada lokasi A $(5,69)$ dan Tertinggi pada lokasi $G(6,08)$. Untuk rata-rata koloni bakteri terendah pada lokasi A $(3,80 \mathrm{CFU} / \mathrm{g})$ dan tertinggi pada lokasi $\mathrm{G}(3,96 \mathrm{CFU} / \mathrm{g})$. Berdasarkan hasil analisa data dan * Alumni Fakultas Peternakan Unsrat
** Jurusan Ilmu Produksi Ternak
\end{abstract}

pembahasan terhadap semua variable pada penelitian ini dapat disimpilkan bahwa daging babi merah yang dijajakan pada rumak makan di Kota Manado memiliki kualitas yang baik dan layak untuk dikonsumsi ditinjau dari kadar air, $\mathrm{pH}$ dan koloni bakteri.

Kata kunci: daging babi merah, kadar air, pH, koloni bakteri

\section{ABSTRACT}

EVALUATION OF WATER CONTENT, $\mathrm{pH}$ AND BACTERIA COLONY OF RED PORK PRODUCT IN MANADO CITY. Red pork is a processing productmeat preferred by consummers in Manado due to specific taste. On the other hand this product was sold at the cafeteria in different qualities. These were generally found on diffirent processing ways, meat sources, spice formulation and smoking time period. Meat quality could be reserved by adding $\mathrm{NaCl}$, sugar, spice and smoking processing ways. The objective of this study was to evaluate water content, $\mathrm{pH}$ and bacteria colony in red pork sold at some cafeteria in Manado. Samples were taken randomly from several cafeteria in Manado and abalyzed at laboratory. Result showed that red pork product sold at several cafeteria in Manado had low average of water content at the A location $(39.1 \%)$ and the highest average of water content at the $\mathrm{G}(56.34 \%)$. The lowest average of $\mathrm{pH}$ was found at the A location (5.69) and the highest average of it at $G$ location (6.08). The lowest average of bacteria colony was also found A location (3.80 $\mathrm{CFU} / \mathrm{g}$ ) and the highest average of it at the $\mathrm{G}$ location (3.96 CFU/g). Therefore, it can be 
concluded that the red pork product sold at the cafeteria in Manado have good quality to be consumed in term of water content, $\mathrm{pH}$ and bacteria colony.

Key words :Red pork product, water content, $\mathrm{pH}$, bacteria colony

\section{PENDAHULUAN}

\section{Latar Belakang}

Usaha peternakan yang bergerak di sektor agroindustry cukup beragam terutama industri pengolahan hasill ternak.Dengan adanya variasi produk olahan komoditi peternakan semakin diminati pleh masyarakat yang menuntut adanya variasi olahan.Salah satu yang dilakukan adalah pembuatan daging babi merah.

Menurut Abustam (2000), daging adalah sebagai bagian dari tubuh ternak yang terdiri dari satu atau sekelompok otot dimana otot tersebut telah mengalami perubahan biokimia dan biofisik, setelah ternak tersebut disembelih. Pada umumnya daging mrngandung unsur -unsur ; air, protein, lemak, mineral dan vitamin.

Pada dasarnya bahan pangan terdiri dari komponen utama yaitu; air, protein, karbohidrat dan lemak. Disamping itu juga bahan pangan mengandung zat-zat organik lainnya misalnya vitamin, enzim, asam, anti oksidan, pigmen dan komponen cita rasa (Winarno et al,,1980).
Menurut Purwati (1983) bahwa kualitas daging merupakan salah satu hal penting baik nagi para konsumen maupun industri yang bergerak dalam pengolahan daging. Kriteria daging yang baik adalah mempunyai warna yang cerah, bau aromatis, konsistensi kenyal, rasa agak manis dank has. Sedangkan Hadiwiyoto (1983) menyatakan ciri-ciri daging yang baik adalah mempunyai penampakan yang mengkilat, tidak berbau busuk, masih elastis atau tidak kaku dan bila dipegang tidak melekat pada tangan.

Sudarisman dan Elvira (1996), daging babi warna merah pucat, mempunyai serat daging halus dan lemaknya berwarna putih.Selanjutnya dikatakan oleh Soeparno (1994), perbedaan daging diantara spesiesternak disebakan oleh perbedaan konsentrasi myoglobin daging.

Pengasapan adalah salah satu cara pengawetan yang memanfaatkan asap sebagai bahan pengawet, dimana pada proses pemanasan dan pengeringan oleh asap yang dihasilkan sehingga dapat besifat bakterisidal (Zigler, 1985)

Tujuan utama pengolahan daging dengan cara pengasapan adalah untuk menghasilkan cita rasa yang baik, memperpanjang masa simpan dan mencegah ketengikan daging akibat oksidasi lemak (Kramlich, 1975) 
Senyawa yang terkandung dalam asap ikut menentukan karakteristik cita rasa daging asap. Selama proses pengasapan komponen asap diserap oleh permukaan produk dan air interestial dalam produk daging asap. Aldehoid, keton, fenol dan asam-asam organic dari asap memiliki daya bakteriostatik dan bakteriosodal pada daging sapa (Urbain, 1981).

Buckle et al., (1987) menyatakan bahwa pengawetan dapat disebakan oleh pengeringan permukaan yang menguap kira-kira $30 \%$ dari pengurangan seluruh berat pada produk yang dipanaskan. Lebih lanjut dikatakan bahwa pengaruh bahan anti oksidasi yang dihasilkan dari pemasukan senyawa-senyawa fenol ke dalam produk pada permukaan yang diasapi, menyebabkan ketahanan masa simpan yang lebih lama dan bebas dari ketengikan sehingga produk akhir dari pengasapan akan memberikan rasa yang khas.

Garam digunakan sebagai bahan pengawet karena berfungsi mengurangi kadar air dalam daging dan menghambat pertumbuhan mikrobia. Ion -ion dalam air akan bergabung dengan molekul-molekul garam sehingga air tidak dapat lagi digunakan sebagai media reaksi dari mikrobia (winarno dan Fardiaz, 1980).
Purnomo

(1985)

bahwa

penambahan NaCI sebanyak $8-10 \%$ dapat mencegah pertumbuhan mikroorganisme dalam daging, akan tetapi penambahan garam sebanyak Ini akan mempengaruhi konsumen karena konsumen hanya dapat menerima rasa asin yang ditimbulkan oleh garam tidak lebih dari $6 \%$.

Afrianto dan liviawaty (1989) menyatakan bahwa selama proses penggaraman, terjadi penetrasi garam dalam daging dan sebaliknya keluarnya cairan dari dalam daging sehingga cairan tersebut melarutkan Kristal garam dalam bentuk partikel dan partikel tersebut masuk dalam daging sampai akhirnya cairan yang keluarberhenti dan membentuk gumpalan protein.

Penyedap didefinisikan suatu bahan baik sendiri maupun kombinasi untuk menambah rasa pada daging olahan (Forest $d k k .$, 1975). Alasan penambahan penyedap ke produk daging olahan adalah untuk membedakan rasa karena formulasi bahan penyedapyang berbeda akan menghasilkan produk daging olahan dengan rasa yang berbeda pula.

Kadar air yang tersedia di dalam daging babi yaitu 60 - 70\% sehingga dapa dikatakan bahwa sebagaian besar daging terdiri dari air (Winarno dan Fardiaz, 1980). 
Menurut Winarno dan Fardiaz (1980) kadar air yang cukup tinggi dalam daging tersebut sangat mempengaruhi mutu daging, oleh karena itu dalam proses pengawetan, air selalu dikeluarkan dengan cara penguapan, pemanasan atau pengasapan. Bakteri da ragi umumnya membutuhkan kadar air yang lebih tinggi dari pada kapang. Menurut Anonim (1979), menyatakan daging babi asap masih dapat dipertahankan apabila mempunyai kadar air $60 \%$.

$$
\mathrm{pH} \quad \text { rendah } \quad(5.1-6,1)
$$

menyebabkan daging mempunyai strukturyang sangat diperlukan untuk pengasinan daging, warna merah muda yang cerah yang disukai dan stabilitas yang lebih baik terhadap kerusakan oleh mikroorganisme (Buckle et al., 1987). Selanjutnya dikatakan $\mathrm{pH}$ tinggi $(\mathrm{pH}$ 6,2 7,2) menyebabkan daging pada daging tahap akhir mempunyai struktur yang tertutup atau padat dengan warna merah ungu tua, rasa yang kurang enak dan keadaan yang memungkinkan untuk perkembangan mikroorganisme

Menurut Budhiarta dan Dirastini (1988); Soeparno (1994) bahwa daging sangat memenuhi syarat untuk perkembangan mikroba, karena daging segar mempunyai $\mathrm{pH}$ yang menguntungkan bagi perkembanangan mikroba sehingga menyebabkan daging mudah mengalami pembusukan. Selanjutnya menurut Nurwantoro dan abbas (1994) bahwa factor-faktor yang mempengaruhi pertumbuhan mikroba dalam bahan pangan dapat bersifat fisik, kimia atau biologis.

Daging akan membusuk apabila jumlah mikroba melebihi dari $5 \times 10^{6}$ koloni/gram atau setara dengan $\log \mathrm{x}=$ 6,69 (Wilson et al., 1981). Menurut Luntungan (1993), jumlah koloni bakteri yang terdapat pada daging babi asap adalah 5.528. Sedangkan menutut Saragih (1999) jumlah mikroba pada daging asap 5,336 .

\section{Materi dan Metode Penelitian}

a. Bahan.

Bahan yang digunakan untuk penelitian yaitu : daging babi merah. Bahan kimia yang digunakanantara lain alcohol (70\%), PCA, Aquades, NaCI $(0,9 \%)$.

b. Alat.

Alat yang digunakan adalah : timbangan analitik Ohaus Galaksy 160, pH meter, tabung reaksi, incubator, auto clave, oven, mikroskop, colony counter, pisau, pinset, cawan petri, termos, pipet ukur, gelas piala dan blender. 


\section{Tempat Penelitian}

Lokasi penelitian ini mencakup rumah makan yang ada di Kota Manado sebagai berikut :

A. Rumah Makan Mie Katan 4 depan Gereja Immanuel Bahu

B.. Rumah Makan Mie Katan 2 depan Bahu Mall

C. Rumah Makan Mie Katan 1 depan Coco

D. Rumah Makan Mie Jakarta depan Fiesta

E. Rumah Makan Mie Katan 3J1 Samrat

F. Rumah Makan Mie Samrat Abadi depan Fiesta

G. Rumah Makan Mie Kitta depan Coco

\section{Metode Penelitian}

Penelitian ini dilaksanakn dengan metode penelitian deskriptif yang digunakan dalam memecahkan masalah dengan menggambarkan keadaan subjeksubjek penelitian berdasarkan fakta-fakta yang tampak sebagaimana adanya, diikuti dengan analisa dan interprestasi rasional terhadap fakta-fakta yang ditemukan di laboratorium dan lapangan.

\section{Prosedur Penelitian.}

Pengambilan sampel dilakukan di beberapa rumah makan yang menjajakan daging babi merah di Kota Manado.Sampel diambil sebanyak tiga kali pengambilan pada hari yang berbeda pada pukul $18.00-19.00 \quad$ WITA.Sampel diletakkan dalam plastic steril yang disimpan dalam termos es kemudian langsung dibawa ke laboratorium untuk diuji.Proses pembuatan daging babi merah pada rumah makan yang ada di Kota Manado disajikan pada Gambar 1.

\section{Variabel}

Variabel yang diukur dalam penelitian ini adalah :

a. Kadar air (Fardiaz, 1988)

b. $\mathrm{pH}$ (Metode AOAC, 1984)

c. Koloni bakteri (Fardiaz, 1988 dan Lay, 1994) 


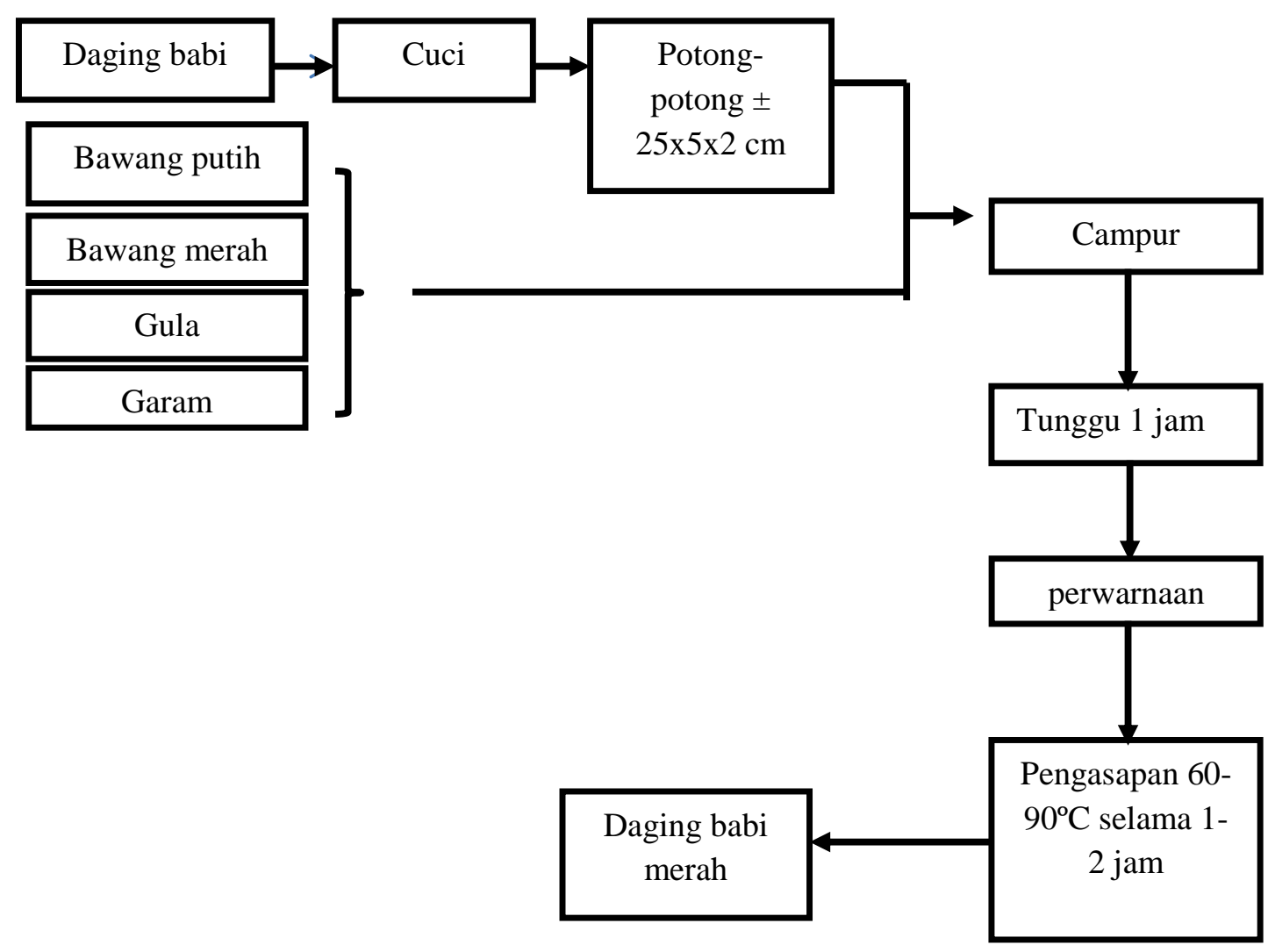

Gambar 1. Diagram proses pembuatan daging babi merah

\section{HASIL DAN PEMBAHASAN}

\section{Gambaran Umum Rumah makan yang} menjajakan Daging Babi Merah di Kota Manado

a. Rumah Makan Mie Katan 4

Rumah makan ini terdapat di kelurahan Bahu, kecamatan malalayang .terletak dipinggir jalan besar dengan bangunan semi permanen (lampiran).
Bagian tempat memasak memilki dinding yang tertutup untuk menghindari kotoran yang masuk dari jalan .

Daging Babi diolah mulai pukul 14.00 - 17.00 WITA.Daging yang telah diolah menjadi daging babi merah dalam jumlah kurang lebih $2 \mathrm{~kg}$, setelah daging babi merah masak diletakkan tergantung di dalam lemari kaca yang tertutup sebelum dibeli oleh konsumen. 
b. Rumah makan Mie Katan 2

Rumah makan ini merupakan salah satu rumah makan yang menjajakan daging babi merah di Kota Manado.Terdapat di kelurahan Bahu kecamatan malalayang terletak dipinggir poros jalan (lampiran 6) Bangunan dari rumah makan ini tidak permanen, terbuka sehingga kotoran dari jalan mudah masuk kedalamnya dan terdapat selokan yang terletak pada bagian samping rumah makan.

Proses pembuatan dimulai pukul 14.00 - 17.00 WITA.Daging babi merah dijajakn berkisar kurang lebih $2 \mathrm{~kg}$.Setelah masak daging babi merah diletakkan di dalam lemari kaca yang tertutup.

c. Rumah makan Mie Katan 1

Rumah makan ini terletak di kelurahan karombasan kecamatan Wanea.Lokasinya berdiri dipinggir poros jalan yang jaraknya cukup jauh dari jalan besar (Lampiran 7). Bangunannya berkisar permanen dan kondisi ruangan terbuka. Proses pengolahan daging babi mulai pukul 12.00 - 17.00 WITA.Daging Babi merah yang diolah kurang lebih 4 $\mathrm{kg}$.Setela masak daging babi diletakkan menggantung di dalam lemari kaca ayang tertutup.

d. Rumah Makan Mie Jakarta
Rumah makan ini terletak di Jl. Sam Ratulangi Wanea, tepatnya di pinggir poros jalan (Lampiran 8).Bangunan bersifat permanen dengan kondisi ruangan tertutup untuk mencegah kotoran - kotoran tidak masuk ke dalamnya. Proses pengolahan daging babi dimulai pukul 14.00 - 17.00 WITA.Daging babi merah yang sudah masak diletakkan dalam lemari kaca yang tertutup.

e. Rumah makan Mie Katan 3

Rumah makan ini terletak di Jl. Sam Ratulangi Kecamatan Wanea di pinggir poros jalan dengan bangunan semi permanen yang semi terbuka.Daging babi diolah mulaii pukul $14.00-17.00$ WITA.Daging babi merah yang sudah masak diletakkan menggantung di dalam lemari kaca yang tertutup.

f. Rumah makan Mie Samrat Abadi

Rumah makan ini terletak di $\mathrm{Jl}$. Sam Ratulangi Wanea di pinggir poros jalan dengan jarak yang saling berdekatan.Bangunan bersifat permanen dan tertutup (Lampiran 10).Proses pengolahan daging babi dimulai pukul 14.00 - 17.00 WITA. Daging babi merah yang sudah masak diletakkan menggantung di dalam lemari kaca yang tertutup sebelum dibeli oleh konsumen. 
g. Rumah makan Mie Kitta

Rumah makan ini terletak di kelurahan Karombasan kecamatan Wanea yakni di pinggir poros jalan, mempunyai bangunan semi permanen yang tidak terlalu besar dengan kondisi terbuka .Daging babi diolah mulai pukul 13.00 16.00 WITA.Daging babi merah yang dijual dengan jumlah kurang lebih 2,5kg.Setelah daging babi merah masak ditempatkan menggantung di dalam lemari kaca yang tertutup.

\section{Kadar Air Daging Babi Merah}

Data hasil analisa dan perhitungan kadar air daging babi merah yang dijajakan oleh para pedagang rumah makan yang ada di kota Manado dapat dilihat pada Tabel 1.

Berdasarkan Tabel 1 bahwa rata rata kadar air yang tetinggi yakni pada lokasi G (56,34\%) sedangkan rata-rata kadar air terendah terdapat pada lokasi A $(39.91 \%)$. Terdapatnya perbedaan rata rata kadar air antara ketujuh rumah makan tersebut karena lamanya proses pengasapan dan suhu yang berbeda.

Proses pengasapan daging babi merah di rumah makan yang dijadikan sampel penelitian umumnya pada kisaran suhu $60-90^{\circ} \mathrm{C}$ dan waktu 1- 2 jam serta ukuran bahan yang diasapi relative kecil sehingga kadar air pada bahan tersebuthilang sekitar $14-30 \%$. Hal ini sejalan dengan pendapat Buckle et al., (1987) yang mengatakan bahwa akibat pengawetan dapat juga disebabkan oleh pengeringan permukaan yang menguap kira-kira $30 \%$ dari pengurangan seluruh berat pada produk yang dipanaskan. Juga dijelaskan Winarno dan Fardiaz (1980) khususnya untuk daging babi asap yang langsung dimakan, suhu pengasapan tidak boleh kurang dari $58,5^{\circ} \mathrm{C}$ karena dibawah suhu tersebut cacing pita yang mungkin terdapat dalam daging tidak akan mati. Lebih lanjut dikemukakan bahwa pengasapan juga berfungsi mengeringkan produk dan membantu membunuh mikroorganisme sehingga produk tersebut menjadi lebih awet.

Tabel 1. Analisis kadar air (\%) pada daging babi merah di rumah makan yang ada di kota Manado.

\begin{tabular}{cccccccc}
\hline & A & B & C & D & E & F & G \\
\hline Pengambilan 1 & 30.42 & 50.94 & 35.62 & 45.62 & 51.42 & 45.03 & 53.79 \\
Pengambilan 2 & 43.72 & 54.72 & 47.16 & 45.82 & 59.2 & 48.2 & 59.6 \\
Pengambilan 3 & 45.60 & 52.70 & 43.20 & 44.90 & 54.30 & 47.20 & 55.63 \\
\hline Rata-rata & 39.91 & 52.79 & 41.99 & 45.45 & 54.97 & 49.81 & 56.34 \\
\hline
\end{tabular}


Tinggi dan rendahnya kadar air yang terkandung pada daging babi merah disebabkan oleh pemanasan yang dilakukan terhadap bahan (daging babi). Menurut Winarno dan Fardiaz (1980) umumnya kadar air dalam daging berkisar antara 60 - 70\%. Kadar air yang cukup tinggi dalam daging sangat mempengaruhi mutu daging olahan, oleh karena itu dalam proses pengawetan air selalu dikeluarkan baik dengan cara penguapan atau pemanasan. Sedangkan menurut Ziegler (1985) lamanya pengasapan tergantung pada suhu pengasapan, jenis kayu, ruang pengasapan dan ukuran bahan yang akan diasapi.

Penambahan gula dan NaCI pada daging babi merah akan menyebabkan pengeluaran air dari bahan tersebut, karena gula dan NaCI berfungsi unutk menyerap air dalam daging babi merah. Purnomo (1995) menyatakan bahwa air dalam bahan pangan berperan sebagai pelarut dalam beberapa komponen disamping ikut sebagai bahan pereaksi, bentuk air juga dapat ditemukan sebagai air bebas dan air terikat. Air bebas dapat dengan mudah hilang apabila terjadi penguapan dan pengeringan, sedangkan air terikat sukit dibebaskan oleh cara tersebut.

Pengolahan dan pengawetan bahan pangan bertujuan antara lain membunuh dan menghambat pertumbuhan mikroorganisme. Tersedianya air bebas dapat menjadi factor utama yang menunjang perkembangan mikroorganisme. Oleh karena itu pengendalian aktifitas air dan kadar air menjadi sangat penting, baik dalam proses pengolahan maupun dalam pengawetan bahan pangan. Hal tersebut erat kaitannya dengan stabilitas pangan.

Jadi kadar air dalam daging babi merah yang ada di rumah makan di Kota Manado memiliki kadar air yang masih baik sehingga produk yang dihasilkan pada beberapa tempat runah makan merupakan produk yang masih aman dikonsumsi.

\section{Derajat Keasaman (pH) Daging Babi}

Hasik Analisis derajat keasaman $(\mathrm{pH})$ daging babi merah pada beberapa rumah makan di Kota Manado disajikan pada Tabel 2.

Nampak bahwa rata-rata $\mathrm{pH}$ tertinggi daging babi merah yakni pada lokasi $G$ $(6,08)$, sedangkan rata-rata $\mathrm{pH}$ terendah terdapat pada lokasi A $(5,69)$. Hal ini diduga bahwa perbedaan $\mathrm{pH}$ pada ketujuh lokasi disebabkan oleh kadar air yang terkandung pada daging babi merah dan proses pengasapan serta banyaknya bumbu yang dicampurkan sebagai pengawet pada sampel. 
Tabel 2. Analisis pH pada daging babi merah di rumah makan yang ada di kota Manado.

\begin{tabular}{cccccccc}
\hline & A & B & C & D & R & F & G \\
\hline Pengambilan 1 & 5.70 & 5.94 & 5.85 & 5.88 & 5.99 & 5.91 & 6.14 \\
Pengambilan 2 & 5.75 & 5.90 & 5.80 & 5.79 & 5.97 & 5.87 & 5.98 \\
Pengambilan 3 & 5.63 & 5.89 & 5.79 & 5.85 & 5.98 & 5.86 & 6.12 \\
\hline Rata-rata & 5.69 & 5.89 & 5.81 & 5.89 & 5.98 & 5.88 & 6.08 \\
\hline
\end{tabular}

Pada proses pemasakan, asap akan diserap oleh permukaan daging sehingga derajat keasamannya akan tinggi akibatnya terjadi penurunan nilai $\mathrm{pH}$. Dengan proses pengasapan yang berlangsung lama mengakibatkan terjadinya penurunan $\mathrm{pH}$ sebaliknya proses pengasapan yang berlangsung singkat mengakibatkan nilai $\mathrm{pH}$ tinggi.

Menurut Soeseno (1985) dan Soeparno (1992), komponen -komponen asap seperti asam asetat, formiat, aseton, butirat dan asam organik lainnya akan menguap dalam asap selama pembakaran kayu berlangsung, sehingga derajat keasaman meningkat, akibatnya terjadi penurunan $\mathrm{pH}$ dalam daging dan membantu menghambat aktifitas mikroba didalmnya.

Nilai pH daging babi merah cenderung menurun dengan penambahan bawang putih.Hal ini disebabkan bawang putih mempunyai $\mathrm{pH}$ rendah sehingga dapat menurunkan $\mathrm{pH}$ daging babi merah yang dicampur dengan bawang putih tersebut.Penelitian yanbg dilakukan oleh
Raharjanti dan Rahayu (2000) nilai pH campuran system pangan dan bumbu gulai yang rendah dari komponen rempah penyusun bumbu yang bersifat asam. Selain itu dapat disebakan oleh fenol dan senyawa sulfur yang terdapat dalam bawang putih yang berifat asam sehingga bumbu yang dicampurkan pada daging sangat mempengaruhi kandunagn asam pada daging tersebut.

Menurut Fardiaz (1989), dalam pengolahan pangan, makanan dapat dibedakan atas beberapa kelompok berdasarkan $\mathrm{pH}$ nya yakni $\mathrm{pH}$ rendah, $\mathrm{pH}$ sedang dan $\mathrm{pH}$ tinggi. Pembagian makanan atas beberapa kelompok ini bertujuan untuk mengetahui daya awet dari suatu makanan, dengan demikian memudahkan mencari perlakuan yang harus diberikan untuk mengawetkan makanan tersebut.Semakin rendah $\mathrm{pH}$ makanan, semakin kurang perlakuan pengawetan pada makanan tersebut. Makanan berasam rendah yaitu makanan yang mempunyai $\mathrm{pH}$ diatas 5,3 misalnya daging, ikan, susu dan lain - lain. 
Dengan demikian dalam pengolahan daging babi merah memerlukan pengawetan yang lebuh selain pemanasan, gula dan $\mathrm{NaCI}$ masih ditambahkan dengan bumbu - bumbuhan agar produk tersebut tahan lama dan terlambatnya pertumbuhan mikroorganisme.

Kadar air yang tinggi dalam daging babi merah sangat berpengaruh terhadap nilai $\mathrm{pH}$, semakin tinggi kadar air dalam daging maka semakin tinggi pula $\mathrm{pH}$ daging tersebut. Sebaliknya semakin rendah kadar air dalam daging maka kandungan asam semakin tinggi atau $\mathrm{pH}$ semakin menurun. Menurut Winarno dan Laksmi (1984), bahwa jumlah kandungan air bebas dalam daging mempengaruhi daya tahan daging dan meningkatkan nilai $\mathrm{pH}$.

$\mathrm{pH}$ daging babi merah yang terdapat di beberapa lokasi mempunyai nilai $\mathrm{pH}$ normal pada bahan makanan yang berasal dari daging. Winarno dan Fardiaz (1989) menyatakan bahwa nilai $\mathrm{pH}$ medium sangat mempengaruhi jasad renik yang dapat tumbuh. Kebanyakan bakteri dapat tumbuh pada $\mathrm{pH}$ optimum dimana pertumbuhannya maksimun yaitu 6,5 7,5. Pada $\mathrm{pH}$ dibawah 5,0 dan diatas 8,5 bakteri tidak dapat tumbuh dengan baik.

\section{Koloni Bakteri Daging Babi Merah}

Berdasarkan pengujian di laboratorium, rata - rata koloni bakteri daging babi merah yang ada di Kota Manado dapat dilihat pada Tabel 3. Terjadinya perbedaan total bakteri pada ketujuh lokasi diduga disebabkan penanganan penjualan, konsentrasi bumbu serta suhu pengasapan daging yang digunakan dalam proses pemasakan. Menurut Fardiaz (1989) mikroba mempunyai suhu maksimum dan minimum sebagai batas suhu pertumbuhannya.Pengaruh suhu terhadap pertumbuhan mikroba disebabkan suhu mempengaruhi aktifitas enzim yang mengkatalis reaksi - reaksi biokimia di dalam sel mikroba.

Tabel 3. Total mikroba pada daging babi merah di rumah makan yang ada di kota Manado.

\begin{tabular}{cccccccc}
\hline & A & B & C & D & R & F & G \\
\hline Pengambilan 1 & 3.81 & 3.93 & 3.92 & 3.94 & 3.95 & 3.95 & 3.95 \\
Pengambilan 2 & 3.78 & 3.95 & 3.85 & 3.74 & 3.93 & 3.88 & 3.98 \\
Pengambilan 3 & 3.80 & 3.93 & 3.86 & 3.83 & 3.92 & 3.84 & 3.96 \\
\hline Rata-rata & 3.80 & 3.92 & 3.80 & 3.83 & 3.89 & 3.70 & 3.96 \\
\hline
\end{tabular}


Koloni bakteri terendah terdapat pada lokasi A, hal ini di sebabkan produk telah memperoleh pemanasan yang cukup sehingga bakteri pada daging merah berkurang.Bakteri pathogen dan perusak makanan umumnya adalah dari golongan mesofik yang mati pada suhu $70^{\circ} \mathrm{C}$ (Buckle et al., 1987).Sedangkan pada lokasi G tingginya koloni bakteri disebabkan oleh pemanasan yang kurang sempurna sehingga masih memungkinkan bakteri untuk tumbuh). Kadar air yang terdapat pada daging babi merah sangat mempengaruhi-pertumbuhan

mikroorganisme. Semakin sedikit kadar air pada daging babi merah, maka semakin berkurang bakteri yang terdapat pada daging babi merah seperti pada lokasi A. Hal ini sependapat dengan Fardiaz (1989) yang menyatakan bakteri memerlukan air untuk hidup dan berkembang biak, oleh karena itu pertumbuhan sel jasad renik di dalam suatu makanan sangat dipengaruhi oleh air yang tersedia.

Pengolahan dengan menambahkan bumbu -bumbu pada bahan makanan seperti bawang putih, bawang merah, selain bersifat menambah cita rasa makanan juga memiliki sifat penghambat terhadap organisme tertentu.Menurut Rahayu (2000) penambahan rempahrempah pada bahan makanan mempunyai aktivitas mikroba yang cukup besar terhadap pertumbuhan bakteri pathogen dan perusak makanan.Lebih lanjut Frazier dan Westhoff (1998), menyatakan bahwa setiap jenis senyawa anti mikroba mempunyai kemampuan untuk menghambat mikroba.

Kandungan pada daging babi merah yang ada di beberapa rumah makan di kota Manado dalam keadaan aman dan layak dikonsumsi dimana rata-rata jumlah bakteri berada pada kisaran 3,80 - 3,96 $\mathrm{CFU} / \mathrm{g}$.

Total bakteri pada daging babi merah masih berada dibawah batas maksimum cemaran mikroba. Wilson et al., (1981) berpendapat bahwa daging mulai membusuk apabila jumlah koloni bakteri melebihi $5 \times 10^{6}$ koloni/gram atau setara dengan $\log x=6,69$.

\section{KESIMPULAN}

Berdasarkan hasil analisa data dan pembahasan dapat disimpulkan bahwa daging babi merah yang dijajakan pada beberapa rumah makan di Kota Manado memiliki kualitas yang baik dan layak untuk dikonsumsi ditinjau dari kadar air, pH dan koloni bakteri. 


\section{DAFTAR PUSTAKA}

Abustam, E 2000. Tehnik Pemotongan, Pengkarkasan dan Meturasi Daging (AGING). Laboratorium Tehnologi Hasil Ternak. Fakultas Peternakan Universitas Sam Ratulangi Manado.

Anonim, E. 1989.Pengawetan dan Pengolahan Ikan. Kanisius Yogyakarta.

Afrianto, E. 1989.Pengawetan dan Pengolahan Ikan. Kanisius Yogyakarta.

AOAC, 1975. Official Methods of the Association of Official Agricultural Chemists. Washington DC

Berhimpon, S. 1974. Pengaruh Beberapa Bahan Pengawet, Lama pengasapan Terhadap Mutu Ikan Mas (Cyprinus carpio) Asap Yang Disimpan Pada Suhu Kamar. Fakultas Perikanan Unsrat, Manado. Afiliasi IPB.

Buckle, K.A.E., G.M. Fleed dan M.S. Wooton. 1987. Ilmu Pangan. Terjemahanoleh H. Purnomo dan Adiono.UI Press Indonesia.

Budhiarta, S dan Y. Dirastini, 1988. Mikrobiologi Makanan Asal Hewan UGM Yogyakarta

Dwidyoseputro, 1964. Dasar - dasar Mikrobiologi. Djambatan Malang

Fardiaz, S. 1989. Keamanan Pangan. PT Raja Grafindo Persada. Jakarta

Fardiaz, S., Sudarwati, N.L Puspitasari, S. Budianto. 1988. Analisa Pangan
( Petunjuk Laboratorium Dedeksi PAU ). IPB. Bogor.

Forest, J C., E.D. Ebenle., H.B. Hendrik., M.B. Judge dan R.A. Michael. 1975. Principle of Meat Science. Company. San Fransisco.

Frazier. W.C. and Westhoff, D.C. 1988. Food Microbiology. New York, MC- Graw Connecticul.

Hadiwiyoto, S. dan Budhiarta, 1990. Kimia dan Teknologi Daging. Proyek Peningkatan Perguruan Tinggi UGM, Yogyakarta.

Ishak, E Dan S. Abdullah. 1985. Zilmu dan Teknologi Pangan. Badan Kerjasama Perguruan Tinggi Indonesia Ujung pandang.

Kramlich, 1975. Procesed Meat. West Port Connecticet The Publishing Company. Inc.

Lay, B.W. 1994. Analisis Mikroba di Laboratorium. PT Raja Grafindo Persada Jakarta.

Nurwantoro da S Abbas. 1994. Mikrobiologi Pangan Hewan Nabati. Kanisius. Yogyakarta

Purnomo, H. 1985. Aktifitas Air dan Peranannya Dalam Pengawetan Pangan.Universitas Indonesia Press. Jakarta.

Purwanti, M. 1983. Proses Memperoleh Daging Sapi Yang Baik dan Sehat Untuk Konsumen. Skripsi . Fakultas Kedokteran Hewan IPB. Bogor. 
Raharjanti, D. S. dan W.P. Rahayu. 2000.

Kajian Pengaruh Pemanasan

Trehadap Aktifitas Anti Mikroba

Bumbu Gulai. Bull. Teknologi dan Indusri Pangan, 11 (1) : $24-29$.

Rampengan, F. J 1985. Dasar - Dasar Pengawetan Mutu Pangan. Badan Pangan. ITB Bandung.

Roberts, S. H. dan S. Karmas. 1989. Evaluasi Gizi Pada Pengolahan Bahan Pangan. ITB. Bandung.

Saragih, L. 1999. Pengaruh Perendaman Dalam Larutan $\mathrm{KNO}_{3}$ dan Lama Penyimpanan Pada Suhu Kamar Terhadap Mutu Daging Sapi Asap. Skripsi.Fakultas Peternakan Unsrat Manado.

Sudarisman dan Elvira. 1996, Petunjuk Memilih Produk Ikan dan Daging Swadaya Jakarta

Soeparno. 1992. Ilmu dan Teknologi Daging. UGM Yogyakarta.
Soeseno, S. 1985. Teknik Penangkapan dan Teknologi Ikan, CV. Yasaguna, Jakarta.

Taib, G.G. Said dan S. Wiraatmadja. 1988. Operasi Pengeringan Pada Pengolahan Hasil Pertanian. Mediatama Sarana Perkasa. Jakarta.

Urbain, M.W. 1981. The Science of Meat and Meat Product and Fresh San Fransisco.

Wilson, N.R.P.E., J. Dyett., R.B. Huges. 1981. Meat and Product, Factor Effecting Cuality Control.

Winarno, F.G.S. dan S. Fardiaz. 1980. Pengantar Teknologi Pangan. PT Gramedia. Jakarta

Winarno, F.G.S. (1993). Pangan Gizi, Teknologidan Konsumen. PT. Gramedia Pustaka Utama. Jakarta.

Ziegler, P.T. 1985. The Meat We Eat The Interestaty. Printers and Publishers. Inc. Danville III 